\title{
Os limites da ordem: respostas à ação da polícia em Vitória ao final do século XIX
}

\author{
Geraldo Antonio Soares
}

\begin{abstract}
Quando criança, em Capitólio, uma pequena cidade no interior de Minas Gerais, meu pai contava-nos uma história de um médico prático, de nome Antero, que aliava à fama de competente na cura de diversas doenças, a partir de medicamentos à base de plantas que ele mesmo manipulava, ao fato, também de conhecimento público, de seu gosto pela bebida. Numa manhã meu pai, encontrando-o já bêbado sendo conduzido até a delegacia por dois soldados, perguntou-lhe então a respeito do que havia acontecido, ao que Antero respondeu com voz arrastada, mas decidida: - Estou aqui dando um repasse nesta tropa do governo.
\end{abstract}

Em um trabalho pioneiro no Brasil utilizando processos criminais como fonte, Maria Sylvia de Carvalho Franco constata que a violência retratada nestas fontes "aparecia por toda parte, como um elemento constitutivo das relaçôes mesmas que se visavam conhecer" e conclui que "foi a violência entranhada na realidade social que fez a documentação, nela especializada, expressiva e válida" ${ }^{1}$ Nossa perspectiva é outra. Para nós o fato da documentação policial e judiciária tratar da violência não constitui prova de que se vivia em uma sociedade violenta, isto porque a violência é a matéria-prima mesma deste tipo de fonte. $\mathrm{O}$ grau de violência existente em uma sociedade só pode ser inferido a partir de uma perspectiva comparativa, seja no tempo ou no espaço.

Partimos da ideia de que embora os processos criminais tratem da violência, nós podemos ir além e perceber neles também um componente de ajuste social e mesmo de convivência social. Um dado que reforça esta nossa opinião diz respeito ao tipo de violência que aí mais aparece, qual seja, a violência interpessoal, como agressões, injúrias e várias outras ocorrências que poderíamos considerar como não sendo graves. Eram essas ocorrências que mais davam trabalho às autoridades policiais e judiciárias em Vitória no final do século XIX.

Outra armadilha que procuraremos evitar é a de pensar as relações daqueles envolvidos nos processos criminais, sejam réus ou testemunhas, com as autoridades judiciais a partir de uma espécie de "dialética da opressão e da resistência”. Como assinala Ivan de Andrade Vellasco, ao tratar do caráter sedutor da ordem ao oferecer ganhos aos que a ela aderem, "parece razoável tratar a atividade policial como uma atividade de vigilância e repressão, o que é, aliás, sua função precípua em toda sociedade; todavia o problema referente ao grau de anuência da sociedade, ou parte dela, a essas atividades não pode ser desprezado". ${ }^{2}$

Procuramos perceber como os indivíduos se relacionavam com a polícia na cidade a partir de inquéritos nos quais as respostas à ação da polícia aparecem de forma mais clara, ou seja, utilizamos os processos que iam além da função investigativa da polícia e nos quais ela aparecia na sua função de responsável pela ordem pública.

Em suas pesquisas sobre a polícia no Rio de Janeiro no final do Império e início da República, Marcos Luiz Bretas parte de uma renovação no corpus de conhecimento da sociologia a respeito da polícia na década de 1860. De acordo com estas novas perspectivas o papel da polícia na sociedade seria mais amplo e não necessariamente restrito a uma visão estritamente legal e formal. Como a polícia acaba por assumir várias funções ou tarefas que não tem como finalidade efetuar prisões ou dar início a procedimentos judiciais,

em muitos casos, o procedimento judicial seria o tecnicamente correto, mas o policial 'decide' agir de forma diferente, conduzindo a situação com outros recursos que não a detenção. [...] Nestas situações a polícia pode frequentemente agir de acordo com as normas legais, mas opta por um outro procedimento, levando em conta uma experiência anterior que lhe apresenta melhores resultados. ${ }^{3}$ 
Em nossas pesquisas também constatamos uma grande autonomia e mesmo uma informalidade na ação da polícia em Vitória à época que, neste caso, não se explica apenas por sua falta de profissionalização, mas também pela grande proximidade das pessoas em relação à polícia na cidade.

Por uma lei estadual de 14 de junho de $1892^{4}$ podemos saber qual era a estrutura hierárquica e o que competia às autoridades policiais no Espírito Santo. Esta estrutura e competência eram definidas respectivamente nos artigos $1^{\circ}$ e $4^{\circ}$ desta lei da seguinte forma:

Artigo 1:: A polícia do Estado é confiada às seguintes autoridades: a) Chefe de polícia com residência na capital; b) Delegados de polícia em todos os distritos inclusive o da capital; c) Subdelegados nos subdistritos policiais inclusive os das sedes dos distritos; d) Inspetores nos quarteiróes dos subdistritos policiais.

Artigo 4ㅇ: A autoridade do chefe de polícia se estende a todo o Estado; a dos delegados será exercida nos seus respectivos distritos; a dos subdelegados não passará dos subdistritos para que houverem sido nomeados; e a dos inspetores será limitada a seus quarteirões.

A divisão em distritos e subdistritos constava do artigo $2^{\circ}$ da mesma lei nos seguintes termos: "Artigo 2o: A administração policial do Estado será dividida em distritos tendo por cabeça as sedes dos municípios, em subdistritos tendo por cabeça as povoações e outros pontos convenientes, e em quarteirões."

Previa ainda o artigo 6o desta lei: "As autoridades policiais, menos os inspetores, deverão ter junto a si um escrivão que poderá ser o mesmo que servir perante o juiz distrital.” Foram estes últimos senhores que muitas vezes nos fizeram "quebrar a cabeça" para decifrar a sua caligrafia.

Trabalhando também com autos criminais e processos judiciais para a província do Espírito Santo no século XIX, Adriana P. Campos chega à conclusão de que a partir desses documentos pode-se perceber "que aos policiais cabia uma ação mais direta com os indivíduos da comunidade local, enquanto do exame dos processos se depreende que à magistratura cabia permanecer nos limites do simbólico, com efeito dissuasório". 5

No contato direto e cotidiano da polícia com a comunidade local não podemos partir de uma ideia equivocada de que estes policiais estariam numa posição acima das pessoas com as quais tratavam, embora eles não deixassem de representar as autoridades constituídas. Em se tratando de uma cidade que possuía apenas entre 3.000 e 6.000 habitantes entre os anos 1870 e 1890, os policiais estavam muito próximos dos demais habitantes da cidade. Além disso, a profissão de policial não era bem remunerada e às vezes o recrutamento era forçado. Referindo-se aos policiais militares do Rio de Janeiro do século XIX, Marcos Luiz Bretas ressalva que, apesar de

agentes da dominação estatal, são eles muitas vezes vítimas do recrutamento forçado e participantes cotidianos dos dramas das vidas da camada de homens livres e pobres. $\mathrm{O}$ engajamento no corpo militar não significava uma mudança de status e o imediato afastamento de sua condição anterior de filhos, irmãos, amigos ou amantes; muito ao contrário, o exercício da atividade policial jamais conferiu atributos positivos na sociedade brasileira, e os policiais conviviam com os mesmos problemas de outros grupos de trabalhadores, e talvez com alguns mais. ${ }^{6}$

Diversos termos de notificação e multa expedidos pela chefia de polícia, relativos ao ano de 1882 , nos dão uma ideia do que competia à polícia e do quanto esta procurava zelar pela ordem na cidade.

No dia 8 de abril de 1882 compareceram perante o chefe de polícia, Adolpho Ubaldino dos Santos e Leopoldino d'Oliveira Leitão, o primeiro residente em Campos, na província do Rio de Janeiro e o segundo em Itapemirim, na própria província. Ambos foram enquadrados no artigo 93 da lei provincial de 10 de maio de 1880 e multados em 100\$000 (cem mil-réis), "visto serem conhecidos como jogadores". ${ }^{7}$ No dia 8 de novembro do mesmo ano, Lourenço da Costa Pinto, sem profissão, e Constantino Vaz da Silva Riscado, padeiro, também residentes em Campos, foram intimados pelo chefe de polícia a retirarem-se da província dentro de prazo de seis dias improrrogáveis sob pena de serem presos, expulsos e de não poderem a ela voltar sem atestado de autoridade competente. A razão desta inti- 
mação foi ter o chefe de polícia "informação oficial de serem o dito Lourenço da Costa Pinto [e o dito Constantino Riscado] jogadores e de jogos proibidos". ${ }^{8}$

Em um auto de infração de posturas municipais de 16 de maio de 1882 consta que compareceu perante o chefe de polícia o italiano Antônio Inverzini, negociante, morador na Rua Conde d’Eu no 31, ao qual se notificou de uma multa de $10 \$ 000$, como infrator do artigo 40 do código de posturas municipais por se achar com a porta de seu negócio aberta depois do toque de silêncio e usar de vozerias em sua casa. ${ }^{9}$ Em um outro auto de infração de posturas do mesmo ano, lê-se:

Sendo presente o sargento da companhia de polícia José Nunes de Oliveira, à casa número 6 à Rua Dois de Dezembro, cuja casa estava cercada com a força policial por ordem do senhor Dr. chefe de polícia; pois que ali se fazia grande algazarra e batuque e toque de sanfona, observando-se da rua indivíduos maltrapilhos e embriagados, que chegavam à janela, depois do toque de silêncio, e sendo por mim sargento rondante declarado ao morador do prédio de nome Francisco Safiat, que achava-se cercado aquele prédio, para o fim de ser imposta a multa, pela infração do art. 48 das posturas municipais; foi a esta mesma hora franqueada a entrada e por mim imposta a multa de dez mil réis a cada um dos turbulentos [...] e, como dispersaramse em paz lavrei o presente auto $[\ldots]^{10}$

Em um auto de advertências feitas a Manoel de Jesus Loyola, Manoel Pinto Ribeiro, João Francisco das Chagas e Luiza Maria da Conceição, datado de 27 de abril de 1882 consta:

[...] presentes o D r. chefe de polícia e os conduzidos acima mencionados, pela referida autoridade foi advertido à cada um dos presos pelo procedimento dos mesmos como vagabundos, designado o prazo de oito dias para que cada um deles mostrem perante a delegacia de polícia de que estão entregues à ocupação séria e a trabalhos decentes. ${ }^{11}$

Estes documentos apresentam o inconveniente de não trazerem a defesa dos acusados, mas felizmente dispomos de outros nos quais os envolvidos procuram mostrar sua inocência.

Um interessante documento - um termo de bem viver - da secretaria de polícia da província do Espírito Santo, datado de 22 de maio de 1880, é aberto nos seguintes termos pelo chefe de polícia:

Constando-me que João Arthur de Oliveira costuma embriagar-se e, neste estado provocar desordens, perturbando assim o sossego público, e que não se entrega à ocupação útil de que possa tirar meios de subsistência, mando que seja o mesmo citado para comparecer na audiência especial que abro na repartição da polícia para ouvir testemunha que deponha sobre o mesmo Oliveira, no dia 24 do corrente às onze horas do dia. ${ }^{12}$

Uma testemunha de acusação, Manoel Pinto Aleixo Netto, de 26 anos, solteiro, empregado público, natural de Vitória, onde é morador, sabendo ler e escrever, declara

que conhece a João Arthur Tesch Horta de Oliveira, sabe que tem um ofício, mas que parece não fazer uso dele, visto achar-se constantemente pelas ruas desta cidade, e tabernas a toa; que lhe consta que o mesmo Oliveira costuma embriagar-se e que ele mesmo testemunha o tem aconselhado muitas vezes para deixar desse vício, e que sabe mais que o indiciado já esteve preso por causa de dar-se ao vício de embriaguez. ${ }^{13}$

O acusado João Arthur Tesch Horta de Oliveira tinha de 34 a 35 anos, era filho da escrava Victoria, solteiro, com profissão de alfaiate e vivendo de agências, brasileiro, natural de Vitória, não sabendo ler e escrever, contesta esta testemunha dizendo

que é falso o que dele disse a mesma testemunha; que ele contestante tem sido encontrado algumas vezes nas vendas é porque tem havido festas nestes dias e o fato de ser sempre encontrado nas ruas é porque mora no lugar denominado Ilha das Caiheiras, perto desta cidade, aonde vem sempre a negócio. ${ }^{14}$

Como testemunha de defesa depõe Francisco de Araújo Rabelo, 21 anos, solteiro, negociante, natural de Portugal, residente em Vitória, sabendo ler e escrever e declara 
que conhece João Arthur Tesch Horta de Oliveira; que sabe que ele tem o ofício de alfaiate, mas que nunca o viu ocupado nele e que o mesmo Oliveira presta-se a fazer qualquer viagem de que se lhe encarrega e de que vive; e que costuma beber nos dias festivos e mais alguns, e que não lhe consta que ele seja perturbador do sossego público. ${ }^{15}$

Domingos Antônio Rodrigues da Veiga, de 24 anos, casado, negociante, natural de Portugal, residente em Vitória, sabendo ler e escrever, se apresenta como testemunha de defesa com um depoimento incisivo dizendo que

conhece ao indiciado João Arthur Tesch Horta de Oliveira há cinco anos, que nunca o viu embriagado e que tem muito servido à ele testemunha de barqueiro por diversas vezes, que o vê sempre procurar trabalho, e que o não tem por desordeiro, visto que nunca o viu em barulho algum e nem foi encontrado armado, e que o tem como muito fiel tanto que lhe tem entregue por várias vezes quantias e cargas. ${ }^{16}$

Mas de pouco adiantaram os esforços de João Arthur em tentar convencer o chefe de polícia de que ele não era um vadio, de que não exercia a profissão de alfaiate, mas que tinha meios de vida, notadamente como barqueiro, que não vivia embriagado, que só bebia em dias de festas e que mesmo nestes dias não incomodava ninguém. O chefe de polícia decidiu pela assinatura do termo de bem viver.

Mas o que significaria precisamente assinar tal documento? Para encontrar tal resposta, passemos ao exame do caso de Possidônia Maria da Conceição, 21 anos, solteira, lavadeira, natural da freguesia de Vianna, não sabendo ler nem escrever, que em julho de 1882 também assinou em Vitória um termo de bem viver, mas que já em novembro do mesmo ano era acusada de desrespeitá-lo.

No dia 26 de julho de 1882, Possidônia Maria da Conceição comparecia à casa do subdelegado de polícia, onde depois de ouvidas as testemunhas de acusação e não tendo a acusada apresentado defesa nem testemunhal nem escrita, "depois de tudo bem visto e ponderado", a autoridade policial mandou que a dita indiciada assinasse o presente termo de bem viver, pelo qual se obrigara a não mais provocar desordem com pessoa alguma, proferir palavras obscenas e empregar-se em um meio lícito de vida que lhe pudesse dar o sustento; sujeitando-se no caso de o quebrar, a trinta dias de cadeia e trinta mil-réis de multa. ${ }^{17}$

Em 3 de novembro do mesmo ano de 1882, Possidônia é novamente acusada, desta vez por quebra do termo de bem viver que assinara. A testemunha João Antônio Villas Boas, 23 anos, casado, profissão de agências, natural e morador em Vitória, sabendo ler e escrever, quando inquirido sobre o procedimento da acusada depois da assinatura do termo e o motivo de sua prisão declara "que sabe que a acusada presente ainda não deixou o costume de espiritualizar-se assim como sempre a vê pelas ruas da cidade não sabendo porém se tem ocupação alguma”. ${ }^{18}$

Em sua defesa Possidônia diz

que tendo o inspetor de quarteirão João Pinto da Victoria Pestana a mandado chamar e tendo ela respondido que nenhum negócio com ele tinha, e a encontrando em disputa com Aurélia Maria da Conceição, na porta da casa de negócio de Maria de tal, pelo vulgo 'Pano fino', mandou, depois de sua volta da fonte de lavar, por um soldado de polícia, prendê-la à ordem do Dr. chefe de polícia, não sabendo por que motivo, visto que quem havia provocado com ela a desordem tinha sido a referida Aurélia. ${ }^{19}$

A acusada acabou sendo condenada a 30 dias de prisão, trinta mil-réis de multa e a pagar as custas do processo.

Nestes e em outros processos que analisamos, constatamos que a preocupação das autoridades com a ordem pública tinha um alvo específico sempre visado: a repressão da vadiagem. Qual a razão de se voltarem as autoridades para esta questão? Por que se procurava forçar estas pessoas a encontrarem uma ocupação útil, muitas vezes fixando um prazo para tal sob pena de prisão?

Tratando da história da polícia na cidade do Rio de Janeiro durante o século XIX, Thomas Holloway constata que a preocupação maior desta instituição era com as ofensas à ordem pública, que, se por um lado, não atentavam contra o indivíduo nem contra a propriedade, por outro, eram comportamentos 
que aqueles que ditavam as regras consideravam inaceitáveis. A polícia da Corte dedicava a maior parte de seu tempo e de suas energias à repressão de transgressóes como vadiagem, mendicância, violação do toque de recolher, desacato à autoridade, insulto verbal, desordem em geral e embriaguez pública. ${ }^{20}$ Como estamos vendo, em Vitória não era muito diferente.

Analisando esta questão do controle social das autoridades policiais sobre os que consideravam como vadios ou desocupados na cidade de São Paulo no final do século XIX e início deste século, Boris Fausto se coloca as mesmas questôes e, a nosso ver, chega a respostas inteiramente satisfatórias que se aplicam também a Vitória.

Boris Fausto descarta como possível resposta razões de ordem política, porque "pelo menos em São Paulo, não há indícios de que os vadios fossem vistos como um estrato socialmente perigoso, capaz de engrossar movimentos de rebeldia contra o poder constituído [...]". ${ }^{21}$ Ainda segundo Boris Fausto, "não é possível também ligar a pressão sobre os vadios a razões econômicas, considerando-a um instrumento necessário para garantir a oferta de mão de obra, pois, de um modo geral não havia este problema na cidade". ${ }^{22}$

Como para São Paulo, também para Vitória a nosso ver a melhor explicação para a preocupação e o controle efetivo que sempre procuravam realizar as autoridades policiais sobre pessoas que elas consideravam como vadios ou desocupados era a de que:

Os desocupados permanentes ou mesmo transitórios eram perseguidos (e muitas vezes tolerados) porque constituíam não um perigo, mas um inconveniente social, tanto quanto os delinquentes com os quais quase sempre se confundem. Os relatórios das autoridades, assim como os projetos de 'regeneração' dos vadios refratários, revelam uma visão da vadiagem como desvio comportamental e não como decorrência de contingências sociais, um indicador adicional de que os vadios não eram encarados como uma ameaça à ordem pública. ${ }^{23}$

Esta preocupação de ordem moral com o "trabalhador-que-não-trabalha" é bem descrita por Robert Castel, comentando a respeito da oposição das classes proprietárias quando da conquista de férias pagas obtidas pela classe trabalhadora francesa nos anos trinta do século XX. Segundo Robert Castel,

a hostilidade "burguesa" às férias remuneradas - comum aos pequenos trabalhadores independentes, aos comerciantes, etc., e a toda a França não assalariada - manifesta bem a perenidade desta clivagem. Esta atitude reativa, para ficarmos apenas num eufemismo, o desprezo secular das classes proprietárias em relação ao trabalhador-que-não-trabalha e que não saberia estar desocupado porque sofre de uma tara moral, não tendo outro emprego de uma liberdade roubada ao trabalho que saciar seus vícios, vagabundagem, bebedeira e lubricidade. Não há qualquer modalidade de existência possível ao trabalhador que não seja o trabalho: não se trata de uma tautologia, mas de um julgamento, ao mesmo tempo, moral e social, comum a todos os bem-pensantes e que encerra o operário num papel sempre associado às tarefas físicas. ${ }^{24}$

Se considerarmos que a família sempre foi considerada como um fator de estabilidade social, um aspecto da composição da população de Vitória devia preocupar as autoridades policiais, qual seja o considerável número de pessoas solteiras. Em 1872, de um total de 3.360 homens e mulheres livres de Vitória, 2.630 eram solteiros. ${ }^{25} \mathrm{Em} 1890$, da população total da cidade de 6.626 pessoas, 5.012 eram solteiros. ${ }^{26}$

Dispomos de dados sobre idade da população de Vitória apenas para 1872. Naquele ano, da população total da cidade de 3.360 pessoas, 571 mulheres tinham menos de 15 anos e 727 homens menos de 20 anos (incluindo 11 homens e 2 mulheres ausentes temporários). Do total de 2.062 homens e mulheres com mais de 20 anos (homens) e de 15 anos (mulheres), 1.332 eram solteiros, o que representava $65 \%$ das pessoas nesta faixa de idade. ${ }^{27}$

Os dados do recenseamento de 1890 também mostram que havia um grande número de pessoas de filiação ilegítima na cidade. Não dispomos de dados a este respeito para 1872, mas em 1890 havia em Vitória 2.100 ilegítimos para uma população total de 6.626 pessoas $^{28}$, ou seja um índice de $32 \%$ de ilegitimidade.

Como observa Elizabeth Kuznesof, se um índice de ilegitimidade desta magnitude for comparado com números sobre a Europa que levantaram pesquisadores como Peter Laslett para a Inglaterra e País de Ga- 
les no século XIX, ele pareceria extremamente elevado. Mas observa ainda a mesma autora, que "estimativas sobre as proporçôes de nascimentos ilegítimos nas comunidades brasileiras dos séculos XVIII e XIX variam entre 5,5\% e 65\%, com várias comunidades registrando entre $20 \%$ e $40 \%$ de ilegitimidade" ${ }^{29}$

Não temos como fornecer uma explicação mais completa para o número de solteiros e de ilegítimos porque não dispomos de dados demográficos tais como idade de casamento, número de mães solteiras etc. No entanto, os traços que existem em nossas fontes são de que as uniões consensuais não formalizadas entre solteiros eram vistas com naturalidade na cidade. Nossas fontes não nos mostram como a Igreja via essas unióes, mas vizinhos e as próprias autoridades policiais as aceitavam bem.

Estamos seguros de que o número de solteiros e ilegítimos em Vitória não implicava ausência de laços familiares. Em nossas fontes encontramos vários casos de pessoas solteiras que viviam juntas, ou amasiadas, e que declaravam esta sua condição em seus depoimentos sem qualquer constrangimento. Um outro dado importante é o de que pelo mesmo recenseamento de 1890, podemos constatar que praticamente não havia crianças abandonadas na cidade. Este recenseamento registra apenas uma criança nesta situação, ${ }^{30}$ um dado para nós surpreendente e que devemos tomar com certas ressalvas porque não temos como verificar se ele correspondia de fato à realidade.

$\mathrm{Na}$ sua função de preservação da ordem, as autoridades policiais fiscalizavam o porte de armas, o qual só era admitido com licença da polícia e sem licença para algumas profissões, como aos médicos no exercício de sua profissão, aos caçadores, que deveriam trazer suas armas desaparelhadas no trajeto da cidade, aos militares e poucos outros. ${ }^{31}$ Quando alguém era flagrado com armas e sem licença para seu porte, evidentemente esta pessoa não podia alegar que o porte da arma em questão era para ela uma necessidade, para apenas ser usada em caso de defesa por exemplo. Neste caso era necessário encontrar uma explicação que convencesse a polícia, e aí a criatividade de cada um entrava em cena.

No dia 26 de maio de 1882, à noite, foi preso em flagrante por porte de armas proibidas João Brand, 30 anos, solteiro, negociante, súdito inglês, natural da Jamaica, sabia ler e escrever, "mas pouco".

Como o acusado "não [era] pessoa tida na conta de vagabundo", ${ }^{32}$ o chefe de polícia ordenou que fosse colocado em liberdade, dando-lhe o prazo de 48 horas para se apresentar novamente à polícia para as devidas explicações.

No dia seguinte o acusado se apresenta com seu advogado que ditou a defesa verbal do réu da forma seguinte:

Declarou que o seu constituinte reside nesta capital a 14 anos, vivendo sempre de profissões honestas, sendo ordeiro e pacífico, respeitador das leis e das autoridades constituídas, e somente o acaso permitiu o encontrar com uma faca na algibeira a patrulha e isto deu-se pela razão seguinte: na 'casa do mercado' onde ele tem dois quartos alugados com um hotel em pequena escala, apareceu-lhe um indivíduo da roça oferecendo-lhe um caixão com ovos, que o mesmo seu constituinte comprara, dando-lhe nessa ocasião o mesmo indivíduo a guardar, uma faca, que recebendo-a, a colocou dentro do bolso do seu palitot que estava sobre uma estaca pendurado. De noite, sabendo-lhe que Maria Justina, cozinheira de seu hotel, havia sido presa pela patrulha, apanhou às pressas o palitot, vestiu-o e seguiu para a Rua da Assembléia desta cidade à casa aonde mora a mãe da mesma Maria Justina afim de comunicar-lhe o ocorrido, feito o que, voltou para sua casa, sendo em caminho preso pela patrulha, a qual nessa ocasião, pegando o mesmo seu constituinte pelo palitot e o puxando com força, a faca desprendeu-se do bolso e foi por ela apanhada [...]. ${ }^{33}$

A denúncia contra João Brand foi julgada improcedente, mas acreditamos que muito mais em razão de seus antecedentes do que pela explicação que forneceu para o fato.

No dia 15 de agosto deste mesmo ano de 1882 foi preso no mercado público de Vitória, Francisco José da Silva, 19 anos, solteiro, marinheiro do vapor Céres, brasileiro, nascido na cidade do Penedo, na província de Alagoas, não sabendo ler e escrever.

O praça de polícia que o prendeu declarou ao juiz que este marinheiro estava no mercado público embriagado e a provocar desordens, pelo que foi mandado que o recolhesse à cadeia para ali ficar detido até que lhe passasse a embriaguez. Mas que ao chegaram à prisão e ao revistar o preso, encontraram 
no bolso de seu paletó uma navalha, pelo que foi de novo conduzido à presença do chefe de polícia por ter sido apanhado em flagrante delito pelo crime de uso de armas proibidas. ${ }^{34}$

Quando perguntado se era verdade o que havia dito a seu respeito o praça de polícia que o deteve, Francisco José da Silva respondeu "que era verdade o que diziam o condutor e as pessoas presentes, mas que a navalha pertencia a José Faustino, morador em São Mateus, que lhe havia dado para ele aqui a mandar amolar por um barbeiro". 35

Os argumentos do acusado não devem ter convencido o juiz, apesar do mesmo tê-lo inocentado, porque em seu despacho este alega que inocentava o réu por ser este rústico e desconhecer a proibição em questão.

Em uma cidade pequena como Vitória, praticamente todos que ali viviam deviam se conhecer. Mas sendo uma capital de província e uma cidade portuária, cabia à polícia exercer o controle sobre os estranhos que por ali passavam. Para isto ela tinha acesso às listas de passageiros de navios e, quando considerava necessário, os convocava para interrogatório a fim de saber as razões pelas quais se encontravam na cidade. Foi o caso de alguns artistas de circo em 1885.

No interrogatório a estes artistas, se perguntou sobre o nome, a idade, estado civil, naturalidade, profissão, filiação, gênero de vida e "atual pretensão".

Nestes interrogatórios de julho de 1885 compareceram, dentre outros, um italiano, de nome Leopoldo Temperani, com 31 anos de idade, profissão artista, que declarou trabalhar em sua arte, sabendo ler e escrever. Compareceu também uma francesa, de nome Paulina Antonietta Magri, nome de família, 21 anos, casada, artista, natural de Paris, sabendo ler e escrever, e que declarou o seguinte sobre seu gênero de vida e atual pretensão: que "tem vivido de trabalhar em circos equestres desde pequena e pretende continuar no mesmo trabalho e talvez aqui mesmo [em Vitória] exiba trabalhos artísticos". ${ }^{36}$

A polícia exercia assim uma vigilância permanente sobre a conduta e, como acabamos de ver, mesmo sobre as intenções de cada um. Tomando na devida conta as diferenças quanto às funções, o nível de organização e os efetivos da polícia parisiense no antigo regime e a de Vitória no final do século XIX, vale citar algumas passagens de Michel Foucault sobre o poder e os limites da ação policial porque elas nos mostram não apenas a onipresença da polícia como aparelho repressor e de vigilância, mas também sua presença mais prosaica no cotidiano da cidade. Segundo Foucault, a instituição policial

É um aparelho que deve ser coextensivo ao corpo social como um todo e não só pelos limites extremos que ele alcança, mas também pela minúcia dos detalhes dos quais ele se ocupa. O poder policial deve se estender "sobre tudo" [...] a todos os acontecimentos, açôes, condutas, opiniōes - "tudo que se passa"; o objeto da polícia, são essas "coisas de cada instante", essas "coisas menores" [...]. Estamos, com a polícia, no indefinido de um controle que procura idealmente se aproximar do grão mais elementar, do fenômeno mais passageiro do corpo social [...]..$^{37}$

Esta é sem dúvida uma das razões maiores pelas quais os arquivos de polícia se revelam uma excelente fonte para a reconstituição da vida cotidiana.

No entanto, devemos ser cuidadosos ao tomarmos a obra de Michel Foucault como um apoio ao exame das forças policiais no Brasil do século XIX e mais ainda para uma pequena cidade como era $\mathrm{Vi}$ tória naquela época. A este respeito, Thomas Holloway tem razão ao observar que

certamente causa impacto descrever a vigilância e o controle totais do panopticon, a depravação dos reclusos e o seu suplício, e depois sugerir que o que aí vemos é claramente a organização do mundo moderno. As atividades policiais, por outro lado, produzem uma amostra muito mais ampla da operação institucional e da resposta pública, na maioria das vezes envolvendo violaçôes menos sensacionais das normas de comportamento e punição menos severa. Saindo da penitenciária para as ruas, devemos passar da fascinação pelo grotesco a uma consideração mais ponderada das banalidades da vida cotidiana. ${ }^{38}$

A polícia em Vitória se ocupava de jogadores, de desocupados, de lavadeiras e marinheiros bêbados, e mesmo de suspeitos de curandeirismo e feitiçaria. 
No dia 4 de julho de 1879 abre-se um inquérito policial em Vitória em que é acusado Antônio Damázio Camillo, vulgo Trem, 38 anos de idade, solteiro, declarando curandeiro como profissão, natural de Valença, na província do Rio de Janeiro, morador em Vitória, não sabendo ler e escrever. $\mathrm{O}$ acusado responde ao interrogatório seguinte:

Perguntado se ele era chamado por alguém nesta cidade para fechar corpo e curar de feitiço? Respondeu que não, que apenas indo à casa da parda Urbana, que mora na Rua da Alfândega, vendo que ela estava doente, perguntou-lhe o que tinha e ela respondeu-lhe que desconfiava que estava com feitiço posto pela crioula Angélica, então ele respondente ensinou à Urbana que comprasse dois ovos, e que cozinhasse-os em aguardente e que depois esfregasse os ovos no corpo, e se fosse feitiço que havia de aparecer, e ela assim fazendo, diz que apareceu-lhe agulhas.

Perguntado se ele fez esses curativos por meio de banhos ou beberagens? Respondeu que fez seus curativos por meio de rezas.

Perguntado que rezas eram essas que usava? Respondeu que era Santo Antônio pequenino.

Perguntado, se além de Urbana, ele tem curado a mais alguém? Respondeu que também rezou ao filho do senhor Neves Xavier, de nome José, saindo do corpo deste vidros e unhas.

Perguntado se sabia por feitiço? Respondeu que por feitiço não sabia; porém que tirar sabia, por meio de suas rezas. ${ }^{39}$

Antes de prosseguirmos neste interessante caso, um pequeno parêntese: Laura de Mello e Souza observa que enquanto na Europa a feitiçaria foi sempre associada à figura da mulher,

é curioso constatar, nas Minas Gerais do século XVIII, a grande incidência de feiticeiros homens - mais numerosos talvez do que as mulheres. Isto se deve em grande parte à sua extração social, homens pobres que eram, negros forros e, algumas vezes escravos; ora, nas culturas primitivas, africanas e indígenas, a magia é desempenhada sobretudo pelos homens. ${ }^{40}$

Depõe no processo Benedito, escravo de Josephina Afonso Martins do Sacramento, 28 anos mais ou menos, solteiro, jornaleiro, natural de Vitória. A autoridade policial pergunta a Benedito se ele foi curado de feitiço pelo acusado, ao que responde

que a vinte dias mais ou menos, ele respondente queixando ao acusado que tinha uma ferida incurável na perna, ele pediu para ver a ferida, e depois de examiná-la, disse que ele respondente estava carregado de feitiço, então tratou de a curar, pediu que comprasse um copo, aguardente, e dois ovos; isto feito, pôs aguardente dentro do copo, e cozinhou os ovos, mandou os quebrar, e nada tinha dentro, porém, pelas costas dele respondente fez aparecer uma moeda antiga de dez réis, que ele respondente conheceu que era artimanha, custando-lhe esse curativo, em dinheiro, dois mil e quinhentos réis, além do que gastou com o copo e a aguardente e ovos. ${ }^{41}$

Admitido ao acusado contestar o depoimento da testemunha, este diz "que tudo era verdade, menos na parte do aparecimento da moeda de dez réis, que ele respondente bem sabia que não tinha saído do ovo". ${ }^{42}$

Também depõe no processo Angélica Maria da Conceição, que ignorava sua idade, solteira, engomadeira, moradora na Rua Francisco de Araújo, natural da própria província, não sabendo ler e escrever. Esta testemunha declara que

vindo ela respondente da roça na terça-feira passada, soube que o acusado estava curando a parda Urbana, e que dissera que ela testemunha era a autora de por feitiço em Urbana, tanto que fez ela respondente aparecer em uma bacia d'água, vestida de vestido verde e tranças de cabelo. Disse mais que hoje soube que o acusado deu remédio à Benedito, escravo de Dona Josephina. Disse mais que soube que o acusado, com seus remédios fez sair do corpo de Urbana umas agulhas de fundo de ouro. ${ }^{43}$

Admitido ao réu contestar a testemunha, este diz "que quanto a mostrar ela na bacia d'água era falso, e que o mais era verdade". ${ }^{4}$

Além de Angélica, de quem Antônio Damázio Camillo dissera que ela havia lançado um feitiço na parda Urbana, também Ladislau, escravo de José da Silva Cabral, 34 anos mais ou menos, solteiro, na- 
tural da própria província e residente em Vitória, parece ter tido o seu nome usado como de alguém que tinha esse hábito pouco salutar de jogar feitiços e que assim dava à profissão de Antônio Damázio Camillo uma grande utilidade social.

Ao ser interrogado, Ladislau diz

que sabendo ele respondente que o acusado tinha dito que ele respondente tinha posto feitiço em Christiano Francisco Ribeiro, ele respondente foi imediatamente ter com este e perguntando-lhe se era verdade o que Christiano se queixara, por ele the foi respondido que não era verdade, e então conheceu que era uma falsidade que o acusado lhe imputava. Disse mais que soube que o acusado dera remédio à parda Urbana, $\mathrm{e}$ que saíra do corpo dela umas agulhas. Disse mais que o acusado aplicou remédio à uma rapariga, Veridiana, escrava de seu senhor Cabral, e de um ovo cozido em aguardente em um saião fez sair umas folhas, por cujo curativo recebeu nove mil-réis, sendo este dinheiro posto debaixo do saião, cujo dinheiro levou, por dizer que não podia ficar em casa da curada. ${ }^{45}$

Como de hábito, dada a palavra ao acusado para contestar a testemunha, "por ele foi dito que quanto ao dinheiro, não era exato a maneira do recebimento, que o senhor Cabral, no dia do curativo, o gratificara com seis mil-réis e no outro dia, três mil e duzentos réis, e quanto ao mais era verdade; e quem o mandara chamar fora o senhor Cabral e sua senhora". ${ }^{46}$

Não consta nos autos qualquer resultado. Assim não ficamos sabendo se o argumento utilizado pelo réu de que "por feitiço não sabia; porém que tirar sabia", produziu algum efeito.

A polícia em Vitória estava longe de se constituir como uma força bem preparada. A violência, a falta de profissionalização e o despreparo da polícia aparecem em casos de excessos e de abuso de poder desta em relação a suspeitos, muitas vezes pelos motivos mais insignificantes.

Segundo Ivan A. Vellasco, quando se parte do princípio de que alguns temas e conceitos como os de Estado, de dominação, de controle social, seriam mais nobres, não se percebe a discrepância entre as funçōes atribuídas, nem tanto pelos contemporâneos, e sim pelos historiadores, à polícia, enquanto instituição capaz de assegurar a vontade ordenadora do Estado imperial, e a realidade que podemos constatar nas fontes que é a precariedade, indigência e toda a sorte de deficiências institucionais que caracterizam este aparato na maior parte do território nacional. Deficiências que passam pela falta de armamentos e uniformes, as péssimas condições das cadeias, o despreparo dos praças e soldados de linha e que fazem com que a polícia pudesse ser mais bem caracterizada como tendo apenas uma função bem limitada: a de uma força precária de contenção de conflitos interpessoais e manutenção de uma ordem possível nas ruas, o que a distanciava muito de uma instituição propriamente de controle social. ${ }^{47}$

Se soldados cometiam excessos pela cidade, excessos estes presenciados por testemunhas, podemos imaginar o que devia acontecer na cadeia pública.

No dia 25 de outubro de 1884, dois homens foram denunciados como suspeitos de serem escravos fugitivos por Manoel Joaquim Gomes, 35 anos, casado, pescador, natural e morador em Vitória, sabendo ler e escrever. Esta testemunha declara no inquérito que

à uma hora da noite mais ou menos, a 25 de outubro do ano passado, indo ele testemunha desta cidade para sua casa na Capixaba, encontrou no alto da Ladeira de Pernambuco, nesta cidade, os dois acusados presentes que saíram de um cafezal que ali tem trazendo cada um deles ao lombo um saco com diferentes objetos, e desconfiando ele testemunha que os ditos acusados, a quem não conhecia, eram escravos fugidos, voltou, e no quartel da polícia, deu parte do ocorrido ao sargento Ribeiro, o qual mandou alguns praças no encalço dos acusados, os quais já foram encontrados pelos mesmos praças e por ele testemunha no cais da obra do Batalha embarcando numa canoa; que nessa ocasião foi preso o acusado João Ferreira, não o tendo sido o seu companheiro Victorino porque, jogando-se ao mar, evadiu-se, $[\ldots]^{48}$

Apurou-se que os dois homens não eram escravos, mas desta suspeita inicial, passou-se então à acusação de roubo à amásia de um deles, do que havia se jogado ao mar. Posteriormente este acusado foi preso. Tratava-se de Victorino Thomaz Dantas, 42 anos, solteiro, pedreiro, brasileiro, sabendo ler e escrever. Nos autos Victorino apresenta as razões pelas quais não se entregou à polícia na ocasião. Diz ele 
que não se entregou à prisão não só porque alterado como estava por efeito da aguardente, não sabia o que fazia, como também porque receava ser maltratado pelos policiais com pancadas, pois ele acusado, que foi praça durante dezessete anos, sabe perfeitamente como costuma ser feito serviço semelhante a este pelos soldados, principalmente quando se trata de pessoas de certa ordem, como ele acusado, e quanto esses serviços são feitos, como naquela ocasião, alta noite. ${ }^{49}$

\section{Como bem lembra Marcos Luiz Bretas,}

o policial tem como expectativa, sempre, o comportamento legal, que aprendeu a valorizar, embora reserve para si um repertório de opções fora da legalidade, das quais lança mão de acordo com sua visão dos 'fatos'. Numa forma simplificada podemos dizer que o leque de opçôes abrange da decisão de não intervir, não ver o que se passa, até o emprego da violência. ${ }^{50}$

Mas encontramos também um inquérito em que a ação da polícia se caracterizava muito mais pelo burlesco que pela violência.

No dia 6 de dezembro de 1881, abre-se uma diligência na delegacia de polícia de Vitória para se apurar as responsabilidades pela fuga do galé Damião, que havia fugido quando saiu escoltado por um soldado para vender chapéus no dia 9 ou 10, ao que tudo indica do mês anterior (há imprecisões nos autos quanto à data exata do fato).

O carcereiro Juvêncio da Rocha Coutinho, 45 anos, solteiro, natural da própria província, sabendo ler e escrever, declara que na manhã do dia 10 o galé Damião saíra escoltado pelo soldado Raymundo de Souza Pegada, para vender chapéus. Explica que autorizara a saída do preso porque o chefe de polícia permitia que presos saíssem para venderem os produtos que faziam na prisão. Ao meio dia, quando do recolhimento dos presos que haviam saído, notou a falta do galé Damião. Prossegue o carcereiro dizendo que

neste ínterim chega o dito soldado dizendo ter o referido preso se evadido; achando-se o mesmo soldado bastante embriagado, do que imediatamente dei parte ao Dr. chefe de polícia. Disse mais que dirigindo-se à Fonte Grande, lugar de onde havia se evadido o preso, ali soube que o soldado Pegada e o galé estiveram em uma taberna próxima ao lugar por algum tempo; voltando porém à fonte, Pegada sentara-se no muro junto a ela e o galé tomou direção para traz do chafariz. Tempos depois despertou Pegada do sono em que se achava e perguntando a algumas lavadeiras pelo preso, responderam-lhe que tinha seguido para trás do chafariz, para onde ele se dirigiu em vão a procurá-lo. ${ }^{51}$

O soldado da companhia de infantaria Raymundo de Souza Pegada, 30 anos pouco mais ou menos, casado, natural do Ceará, não sabendo ler e escrever, nos dá mais detalhes desta história que certamente a polícia do Espírito Santo teria preferido que continuasse adormecida nos arquivos. Quando perguntado como se tinha dado o fato da evasão do galé Damião, confiado à sua guarda, o soldado Raymundo Pegada nos diz

que saiu com o galé Damião para vender uns chapéus e depois de haver efetuado a venda, pediu mais para ir à Fonte Grande dar um pouco de roupa a lavar; nesta ocasião pediu para fazer uma precisão, à qual ele respondente concedeu, e seguiu para traz da caixa d'água, sempre à sua vista, mas encoberto com o mato. Tendo decorrido algum tempo, ele respondente chamou-o e não lhe respondendo, foi ao lugar e não o encontrou. Tratou de procurá-lo imediatamente por aquelas imediações e perguntou a algumas lavadeiras que se achavam em uma fonte particular se tinha passado ali um preso, elas lhe responderam que não, ao que ele respondente subiu o morro, procurando-o em vão por diversos lugares, não continuando a o fazer por ter sido chamado à guarda da cadeia, onde estava de serviço. ${ }^{52}$

Referindo-se às classes populares inglesas no início do século XX, Richard Hoggart observa que as relações destas pessoas com a polícia "não são sempre tensas, mas, sejam elas boas ou más, o agente de polícia é antes de tudo aquele que representa a autoridade, aquele que 'está de olho em você', e não o funcionário pago para tirá-lo das dificuldades ou para protegê-lo". ${ }^{53}$ 
Poderíamos dizer que a polícia em Vitória também não era vista como uma instituição que protegia as pessoas e nem que representava uma autoridade bem definida ou reconhecida. O quadro da polícia em Vitória ao final do século XIX estava mais próximo do descrito por Ivan A. Vellasco para todo o território nacional na primeira metade daquele século, não estando Vitória entre as capitais de província que constituíam uma exceção:

Consideradas as condições materiais e os efetivos das forças regulares encarregadas da manutenção da ordem pública durante a primeira metade do século XIX, poderíamos afirmar que na maior parte do território nacional, à exceção da Corte e de algumas capitais de província, parece ter existido uma sociedade sem policiamento. $\mathrm{Ou}$, pelo menos, uma sociedade na qual a existência da polícia foi muito pouco relevante. ${ }^{54}$

Em Vitória, a visão que tinha a polícia do que era a ordem social e do seu direito de mantê-la era muito diferente daquela que tinha o homem comum. Percebemos em vários momentos que as pessoas tinham uma clara definição de limites para a polícia. Quando esta ultrapassava esses limites, a reação era imediata.

Esta reação das pessoas comuns, fixando a barreira além da qual a polícia não devia ir, não se dava por explosôes de violência, motins etc. Eram reaçôes individuais, que no entanto encontravam apoio em grupos mais amplos, sejam de vizinhos, de passantes na rua que presenciavam algum conflito do qual a polícia era participante, ou de modo geral, de testemunhas que depõem nos processos. A impressão que ficou para nós é que se tinha uma grande prevenção em relação à polícia. Em alguns casos, chegamos a ter a sensação de que as pessoas, implicitamente ou inconscientemente, pareciam estar de acordo para desautorizar e mesmo ridicularizar as autoridades policiais.

Havia também reaçōes que nos mostram que a definição de quais eram os limites permitidos à polícia envolvia uma questão de definição do seu poder de coerção ou de repressão de forma mais geral, e objetivamente em relação a resistências que se colocavam ao que se entendia como sendo espaços, senão privados, ao menos não franqueados à polícia.

No dia 29 de janeiro de 1890 é aberto um inquérito policial a partir da seguinte denúncia da Promotoria Pública:

Levo ao vosso conhecimento que ontem pelas onze horas da noite, ao passar pela porta do negociante João Coutinho da Victoria, os agentes José Gomes Dias da Silva e José Vicente do Espírito Santo, este ao ver ainda a porta aberta, pediu em bons termos que não continuasse com a porta aberta, o que respondeu o mesmo Coutinho, que a polícia não devia se intervir com sua porta e que quem podia fechá-la eram seus credores e que eles se retirassem; advertindo o mesmo agente, e mesmo porque ali era o lugar que sempre se aglomeravam praças e que para que não se desse algum distúrbio, o pediu; deu lugar que Coutinho levantasse, com a cadeira em punho, trouxe a polícia à mais baixa inobservância, em altas vozes, e declarou mesmo que a polícia daqui era de merda e esta que se... (faz vergonha declarar) e que os agentes e ela mesma que vão à porra (termos dele). ${ }^{55}$

Passavam pelo local naquele momento, Cypriano Alves da Cunha, 35 anos, solteiro, empregado público, morador em Vitória e natural da própria província, sabendo ler e escrever, e Ludgero Francisco Guimarães, 31 anos, solteiro, também empregado público, morador e natural de Vitória, sabendo ler e escrever. Ambos declaram que passavam por ali por acaso e que presenciaram a discussão, confirmando que o comerciante João Coutinho da Vitória realmente havia desacatado a polícia com palavras injuriosas e que ofendiam a moral pública. As duas testemunhas também informam que no momento da discussão chegou Cândido de Miranda Freitas Júnior, o qual conseguiu fazer com que o comerciante João Coutinho se retirasse para o interior da casa. ${ }^{56}$

Cândido de Miranda Freitas Júnior, 33 anos, casado, empregado público, morador e natural de Vitória, não sabendo ler e escrever, depõe no processo declarando o seguinte:

Que com efeito estando conversando com o cidadão Augusto Nunes da Silveira no pavimento térreo da casa de sua residência, à Rua da Assembleia, foram despertados por uma vozeria entre o negociante João Coutinho da Victoria e os agentes policiais José Gomes Dias da Silva e José Vicente da Conceição, com trocas 
de palavras obscenas. A conselho do cidadão com quem conversava, dirigiu-se ao negociante Coutinho, pedindo-lhe que fechasse a sua porta, a fim de que terminasse a discussão estabelecida entre ele e os agentes; no que foi prontamente atendido; sabendo mais do dito Coutinho, que a este procedimento foi levado, por ter um dos agentes o insultado, ofendido seus créditos de comerciante; tendo esse fato se dado às onze horas, pouco mais ou menos. ${ }^{57}$

No depoimento citado acima, Cândido de Miranda se refere à pessoa com quem conversava em sua casa como um cidadão. Esta forma de tratamento constitui uma raridade em nossas fontes. Mas este processo é de apenas dois meses e meio após a proclamação da república no Brasil, em 15 de novembro de 1889.

Cândido de Miranda era um vizinho do comerciante que entendia que, além dele, só os seus credores tinham direito de fechar o seu negócio; ao que tudo indica, um pequeno bar. Em momento algum esta testemunha diz que o comerciante teria ofendido os policiais. Diz apenas que houve troca de palavras obscenas e que o seu vizinho reagiu daquela forma porque os policiais teriam ofendido os seus brios de comerciante. Tratando da polícia parisiense de meados do século XVIII, Arlette Farge e Jacques Revel afirmam que a mesma possuía a seguinte representação da tranquilidade pública: "A ordem pública deve ser gerida pelas autoridades e apenas por elas; a única atitude que compete ao povo é conformar-se com elas". ${ }^{58}$ Como vimos, o problema é que o comerciante em questão não se conformava.

Um outro aspecto interessante da situação aparece na própria denúncia, na parte em que o policial intima o comerciante João Coutinho da Vitória a fechar as portas de seu negócio. O policial advertiu o comerciante da necessidade de fechar as portas por ser ali um lugar onde se aglomeravam praças de polícia e, assim, propenso a distúrbios. O estabelecimento de João Coutinho ficava próximo ao quartel da polícia, os policiais o frequentavam e ele ainda estava aberto às onze horas da noite, de onde deduzimos que devia se tratar de um pequeno bar.

A situação não deixa de ser paradoxal. Para manter a ordem, dois policiais intimam um comerciante a fechar seu estabelecimento. Mas se reconhece que um dos riscos de perturbação da ordem estava na própria polícia, já que policiais frequentavam habitualmente o local e provocavam distúrbios. A polícia procurava se proteger dela mesma. Talvez tenha sido nesse momento que o comerciante João Coutinho da Vitória achou que as coisas estavam passando de seus limites.

No dia 17 de novembro de 1897, em torno de cinco horas da tarde, aglomerou-se o povo na Rua Duque de Caxias, esperando a passagem de um preso que vinha escoltado por dois policiais e um tenente, este último vindo a cavalo.

Honório João Rabelo, 34 anos, casado, negociante, morador em Vitória, natural do próprio Estado, sabendo ler e escrever, presenciou o que então aconteceu:

Disse que achava-se na porta de seu estabelecimento, quando avista, vindo pela Rua Duque de Caxias, um preso escoltado por dois praças e o tenente Elísio a cavalo; o povo que se achava no Largo da Alfândega, viera pelo beco entre a casa de Cesário e a do Sousa, afim de vê-los passar, nisto, sem motivo algum começou o tenente Elísio a atropelar o povo, metendo o chicote a torto e a direito, dando lugar a que muitos se refugiassem em casa de Cesário e outros corressem e que chegando nessa ocasião o capitão Barbosa e o alferes Aristides, entraram no estabelecimento de Cesário e tocavam para fora o povo que ali se achava à socos e pontapés, sendo que estes ainda cá fora eram espancados pelo tenente Elísio; que Cesário, pulando do balcão para fora a fim de trancar as portas do seu estabelecimento, foi também espancado pelos referidos capitão e alferes, que o arrastaram para fora de sua casa, sendo ainda do lado de fora, espancado pelos mesmos oficiais e pelo tenente Elísio, que com o cabo do chicote descarregara-lhe diversas bordoadas, e que o tenente Elísio, na ocasião do barulho procurou por mais de uma vez servir-se do revólver que consigo trazia. Que todos os fatos que acaba de narrar foram presenciados por grande número de pessoas. ${ }^{59}$

Frederico Constâncio de Mattos, de 32 anos de idade, solteiro, artista, morador em Vitória, natural do próprio Estado, não sabendo ler e escrever, também estava presente. Mas antes de passarmos ao seu depoimento, um pequeno parêntese no qual aproveitaremos a oportunidade para esclarecer o que 
significava esta profissão de artista, antes que sejamos levados a crer que Vitória era uma cidade onde a cultura se expandia de vento em popa porque várias pessoas declaravam artista como profissão.

Frederico Constâncio de Mattos já apareceu em nossas fontes como o maior amigo dos escravos Marcellino e Florêncio, quando estes escravos foram acusados de roubo em novembro de $1884 .{ }^{60} \mathrm{Na}-$ quela ocasião Frederico declarou pedreiro como profissão. Na verdade Frederico não mudou de profissão entre 1884 e 1897. Por estes e vários outros inquéritos, chegamos à conclusão de que o sentido do termo artista é próximo do de artesão independente. Pedreiros, marceneiros etc., muitas vezes declaram terem a profissão de artista.

Voltando aos acontecimentos daquela tarde de novembro de 1897 na Rua Duque de Caxias, passemos ao depoimento de Frederico de Mattos, no qual podemos constatar que a sua versão dos fatos coincide quase que inteiramente com aquela apresentada pela testemunha Honório João Rabelo. Mas Frederico é ainda mais incisivo na parte de seu depoimento que diz que o povo foi atacado pelos policiais sem que tenha dado motivos para isto. Nos diz ele "que o povo nenhum motivo deu para o procedimento daqueles oficiais pois nenhuma manifestação fizeram contra a prisão, ou contra os mesmos oficiais e que somente por curiosidade aglomerou-se para ver a passagem do preso, como é de costume" ${ }^{61}$

Estaria o povo ali reunido realmente passivamente, apenas como espectador?

Pode ser que sim. Mas não temos como deixar de pensar nas observações de Michel Foucault sobre a forma como o povo assistia às execuçôes públicas na França do Antigo Regime, e fazer certas associações, que no caso são inevitáveis.

Michel Foucault nos diz que:

O horror dos suplícios acendia focos de ilegalismo: nos dias de execução, o trabalho era interrompido, os cabarés ficavam cheios, insultavam-se as autoridades, lançavam-se injúrias ou pedras ao carrasco, aos policiais e aos soldados; procurava-se apoderar do condenado, seja para salvá-lo ou para melhor acabar com ele; brigava-se, e os ladrões não tinham melhor ocasião que a agitação e a curiosidade em torno do cadafalso. ${ }^{62}$

Se as relações das pessoas comuns com a polícia na cidade nem sempre eram tranquilas, problemas parecidos também parecem ter sempre existido entre a população e os fiscais da câmara municipal encarregados de zelar pelo cumprimento do que dispunha as posturas municipais. Notamos que havia uma intolerância muito grande em relação ao trabalho desses fiscais. As multas emitidas eram tidas como injustas pelos que eram multados, o que, aliás, seria de se esperar. Mas não se tratava de simples reações individuais. Havia uma questão mais de fundo, que era a de que a aplicação das interdições previstas nestes códigos de posturas era percebida pela população como um cerceamento do espaço público, uma forma de controle do acesso e do uso da própria cidade.

No dia 30 de agosto de 1877 abre-se um processo em Vitória a partir de uma acusação do procurador da câmara municipal, Galdino Pinto da Terra. A denúncia foi apresentada nos seguintes termos:

Tendo ontem pelas quatro horas da tarde, pouco mais ou menos, chegado uma canoa da pesca com peixe fresco no porto do Hotel Goulart e ali vendido peixe, e sendo isto uma transgressão das respectivas posturas e regulamento da Praça do Mercado, fui chamado pelo guarda daquela praça, a mandado do respectivo fiscal, e ali chegando denunciou-me o guarda policial Antônio da Rocha, que havia proibido a Benedito Pinto do Rozario, mestre da dita canoa para que não vendesse peixe fora da praça, e como se verificasse aquela transgressão passei a multar ao dito mestre da canoa como incurso no art. 116 do código de posturas; porém no ato em que me achava no desempenho das funçōes de meu cargo, em companhia do referido fiscal e guarda servente da praça, compareceu José Goulart de Souza, e tomando parte no ato, após a um baldão de insultos a nós dirigido, e até à corporação da comarca, disse que a multa era arbitrária, mas que ele pagava pelo infrator, e ainda não satisfeito lança-me uma nota de dez mil-réis à cara, dizendo ele, que cinco mil-réis era para pagamento da multa, e os outros cinco mil réis dava de esmola para encher a barriga dos miseráveis empregados da Câmara [...]. ${ }^{63}$

O acusado José Goulart de Souza era o proprietário do Hotel Goulart e compadre do pescador acusado de estar vendendo peixe no porto do referido hotel, o que era proibido (a venda de peixe só era 
autorizada na Praça do Mercado). Do processo pode-se inferir que o referido hotel teria um porto particular, o que não é bem exato. Não se tratava propriamente de um porto e sim de um simples local de atracação de pequenos barcos e canoas. Todas as casas que davam fundo para o mar tinham à época esses pequenos atracadores.

Depõe no processo em que José Goulart de Souza é acusado de injúrias. João Correa dos Santos Marinho, 31 anos, empregado público, solteiro, natural da própria capital e nela residente, sabendo ler e escrever. Diz esta testemunha

\begin{abstract}
que na tarde de um dos dias de meses passados, cuja data não pode precisar, recordando-se apenas que fora neste corrente ano, entrando na Praça do Mercado observou que algumas pessoas achavam-se reunidas à porta de um dos quartos do mesmo mercado, e de outras mais, distinguiu o procurador da câmara, Galdino Pinto da Terra, com uma nota de dez mil-réis nas mãos, dizendo: 'Vou comer, pois preciso muito dela'! Por curiosidade ele testemunha aproximou-se e soube que tratava-se de uma multa, que fora pelo mesmo procurador imposta ao pescador Benedito pelo fato de haver vendido peixe ao denunciado fora da Praça do Mercado. Neste ato apareceu o denunciado que, defendendo o pescador, seu compadre, disse que se ele estava no caso de ser multado por infração das posturas municipais, também o presidente da Câmara, referindo-se à Caparica, o fiscal e o procurador estavam no caso de serem multados por infratores, como ele denunciado provaria; dito isto, ia o denunciado a retirar-se quando foi chamado pelo procurador para receber o troco; ao que o denunciado respondeu dizendo que não precisava, que ficasse com ele; respondeu o procurador que o não queria, e então, o denunciado disse-lhe que o desse aos pobres; depois do que retirou-se o denunciado, assim como ele testemunha, que por esta razão de nada mais sabe. ${ }^{64}$
\end{abstract}

Em sua defesa por escrito, José Goulart de Souza, 44 anos, casado, comerciante, natural de Vitória, sabendo ler e escrever, alega que não proferiu injúria verbal alguma contra quem quer que seja, que sentiu a maior surpresa ao ver-se processado por injúrias verbais "contra uma corporação distinta, pelo caráter solene que a reveste". Diz ainda que "na verdade causa mágoa ver-se assim perturbada a tranquilidade de qualquer cidadão, por motivos frívolos, isto é, sem o menor fundamento jurídico" ${ }^{65} \mathrm{Em}$ relação à acusação propriamente dita, diz que entre ele, o procurador Galdino Pinto da Terra, e o exfiscal da Câmara, Manoel Pinto Aleixo, houve simplesmente uma conversa sobre a multa imposta a seu compadre Benedito, na qual pronunciou-se dizendo que este ato parecia-lhe injusto. Conclui alegando que "o abaixo assinado não conhece o código que estabeleça pena para punir o juízo particular que forma cada um sobre qualquer fato, elogiando ou censurando o mesmo" ${ }^{66}$

A denúncia foi julgada improcedente.

Neste processo podemos perceber não só que o acusado contestava a multa aplicada a seu compadre, como também contestava as autoridades municipais, insinuando que elas mesmas não cumpriam os regulamentos de que eram responsáveis. Tudo isto apesar dos termos respeitosos de sua defesa. Nos parece que o Sr. José Goulart de Souza tinha consciência dos limites da lei nos termos de Edward P. Thompson, ou seja, sabia "que a maior de todas as ficções legais é a de que a lei se desenvolve, de caso em caso, pela sua lógica imparcial, coerente apenas com sua integridade própria, inabalável frente as considerações de conveniência". ${ }^{67}$

Três anos antes era apresentada em juízo uma denúncia tratando de um assunto parecido. Mas nesta denúncia de 9 de maio de 1874, de certa forma os papéis se invertem, porque agora é alguém que foi multado que apresenta uma curiosa denúncia contra o fiscal da Câmara que o multou.

Jorge Tiburtino de Andrade, brasileiro, morador em Vitória, apresenta queixa contra Jacintho Escobar Araújo, 45 anos, casado, fiscal da câmara municipal da capital, brasileiro, natural de Vitória. Os termos da queixa eram os seguintes:

Na noite de cinco do corrente mês, havendo o queixado de seguir viagem, amarrara o seu cavalo na porta da sua residência, onde dava-lhe a ração de milho; e tendo outros afazeres, ali deixara o animal. Quando precisara do animal, já não o encontrara na porta de sua casa, onde o deixara; resolvera o queixoso o procurálo por toda a cidade e não o encontrara. 
Debalde o queixoso não só por si achava-se em busca, como também mandara procurar o cavalo; eis que é o dito animal encontrado na chácara do acusado situada na Fonte Grande, amarrado entre umas pedras; pedira-lhe que lhe fosse entregue o seu cavalo; de dentro da casa respondera-lhe que o cavalo estava preso, porque o queixoso infringira os artigos das posturas municipais; e para dali levar o cavalo era preciso que pagasse a multa no valor de dois mil-réis.

O que fora feito pelo queixoso, não se lhe dando conhecimento de haver pago a multa e mais tarde soube que lhe tiraram o animal da porta e o prenderam sem ser ele conduzido para o depósito público, e como o fiscal tem um moinho para moer milho, tem por hábito mandar prender animais alheios para trabalhar em seu moinho, e desde que o proprietário reclama, ele alega que se acha preso.

Tanto que ele não lavra de conformidade com a lei o auto de infração de posturas, como prova o documento junto, e muito menos mandou intimar ao queixoso para tirar o seu animal e pagar a multa, como é do seu dever.

Ao passo que para uns o acusado, como fiscal, procede com tanta energia, para outros tem a mais excessiva benevolência, ao ponto dos seus animais percorrerem dia e noite as ruas da cidade. ${ }^{68}$

Reforça os argumentos da acusação o depoimento de Aureliano Manoel Nunes Pereira, 39 anos, casado, natural e residente em Vitória, sabendo ler e escrever. Esta testemunha declara que

que em um dos dias do mês de maio, estando à porta da casa de sua residência, aparecendo-lhe o queixoso com uma carta e pediu-lhe que a lesse; o que fez ele testemunha lendo o seguinte: que Antônio Ignácio Rodrigues pedia ao acusado o favor de soltar o cavalo do queixoso, que se achava preso em sua chácara; e que o liberasse da multa por esta vez. Na mesma carta a seguinte resposta do acusado: não podia servi-lo no que pedia, porque libertara [o de] Antônio Ignácio, [do] capitão Laranja, e do escrivão Augusto, que constantemente vagavam pelas ruas, sem que pudesse ele cumprir seus deveres; isto quando à apreensão do cavalo, quanto porém ao hábito de mandar prender animais para ocupá-los no serviço de seu moinho, como se diz na queixa, ele testemunha tem ouvido, vagamente, acusar-se disso o réu, mas de positivo nada sabe ele testemunha. ${ }^{69}$

O acusado, Jacintho Escobar Araújo, apresenta defesa por escrito nos seguintes termos:

[...] Em outubro do ano próximo passado, quando fui nomeado fiscal da câmara, não existindo curral do Conselho, pedi e obtive autorização do atual presidente da municipalidade (atestado junto) para provisoriamente estabelecer o dito curral na chácara que possuo na Fonte Grande; assim ali é que desde esse tempo até hoje faço depositar os animais, que vagam pastando pelas praças e ruas da cidade.

Quando assim tenho praticado constantemente em cumprimento dos meus deveres, como fiscal, e em observância das posturas municipais, não poderia sem censura abrir exceção ao cavalo do queixoso, que nenhum privilégio tem. Portanto na noite de seis de maio próximo passado, pastando este animal solto, e à vontade pelas ruas, mandei prendê-lo e conduzi-lo para o curral do Conselho. Nestas circunstâncias e visto que não poderia ser entregue ao seu dono sem o pagamento da multa de $2 \$ 000$ estabelecida para este caso de infração ao código de posturas.

[...] O queixoso pretende abalar a minha reputação como fiscal da câmara, visto que entendeu, como confessa em sua queixa, que eu não deveria para com ele proceder com tanta energia; [...] Desde novembro do ano passado que o meu moinho está desconcertado, como é notório, faço constar com os documentos juntos, que exibo para por em relevo a inexatidão da queixa, quando imputa-me o plano ignóbil de mandar prender os animais alheios para trabalharem em meu moinho. Se eu empregasse neste serviço o queixoso, ou seu cavalo, ou ambos ao mesmo tempo, pagaria o jornal ou aluguel, que merecessem, e certamente não iria agarrá-los na rua $[\ldots] .^{70}$

Vale notar neste caso que o queixoso Jorge Tiburtino não contesta que tenha infringido o código de posturas municipal, não contesta também a multa, a qual pagou prontamente. $\mathrm{O}$ que ele visa com a queixa é claramente atingir a autoridade do fiscal da Câmara, dando contornos oficiais ao que já era comentado pelo povo, expondo assim mais ainda o dito fiscal da Câmara.

A denúncia foi julgada improcedente. Mas fica a impressão de que o queixoso atingiu seu objetivo, porque a reputação do fiscal Jacintho Escobar não foi restabelecida e sim acaba mais comprometida pela exposição oficial das suspeitas que pesavam sobre ele. Esse nos parece um caso típico de um acusador que sai moralmente vencedor da contenda, na medida em que "o fato de ser citado na justiça por al- 
gum tipo de delito já implicaria transtornos e custos, inclusive materiais, capazes de dissuadir e refrear as ações futuras daqueles que se viam sob a esfera de ação e alcance dos juízes". ${ }^{11}$

No dia 25 de novembro de 1872 abriu-se um inquérito policial contra Manoel Ferreira Dias pelas seguintes razões que constam na denúncia:

O chefe de polícia desta província, vindo no conhecimento de que Manoel Ferreira Dias, súdito português, morador nesta cidade, acaba de efetuar a alienação de um relógio de ouro no valor de trezentos mil-réis $(300 \$ 000)$ por meio de sorte fazendo correr esta loteria ou rifa ilegal anexa a uma das loterias extraídas na Corte do Rio de Janeiro, para cujo fim expôs à venda e realizou a tiragem [?] de cem bilhetes à razão de $3 \$ 000$ cada um [... $]^{72}$

Passa-se então ao interrogatório de alguns compradores de bilhetes e as respostas são reveladoras de um aspecto fundamental da situação, qual seja, o de que as autoridades levaram o delito muito mais a sério que essas pessoas. Poderíamos dizer mesmo que os compradores dos bilhetes não viam nenhuma ilegalidade em se fazer uma rifa com fins particulares. Esta não deixa de ser uma atitude inusitada na medida em que era de conhecimento público que quem acabou por ganhar o relógio rifado foi um filho menor do próprio Manoel Ferreira Dias.

Antônio Pinto Aleixo, 28 anos, solteiro, empregado público, morador em Vitória, sabendo ler e escrever, respondeu, dentre outras, às seguintes perguntas:

Perguntado se sabe a quem coube, por sorte, o relógio rifado? Respondeu que sabe, porque o próprio Ferreira Dias lhe disse que saíra para um seu filho.

Perguntado que idade tinha o filho do dito Dias? Respondeu que supõe ser menor de 15 anos.

Dada a palavra ao Dr. Promotor Público, fez este as seguintes perguntas:

Perguntado se sabe se o filho de Dias, que é menor, a quem saiu por sorte o relógio, mora com o seu pai ou em teto diferente, fora da companhia dele? Respondeu que parece que mora com seu próprio pai, debaixo do mesmo teto.

Perguntado se sabia informar quem escolhera o bilhete ao qual coube o relógio, se fora o próprio pai, o próprio filho ou alguém? Respondeu que não sabe.

Perguntado se para ter lugar o curso da rifa, se foi convidado ou não por Dias, antes ou durante a venda dos bilhetes? Respondeu que fora durante a venda.

Perguntado se em tempo algum ele testemunha ou outras pessoas que compraram os bilhetes nutriram desconfiança contra o autor acerca do êxito da rifa? Respondeu que quanto a si, não teve desconfiança alguma. Perguntado sobre o conceito de Manoel Ferreira Dias para ter comprado bilhete por ele emitido em rifa? Respondeu que nutre os melhores conceitos.

Perguntado se os bilhetes foram assinados por Dias? Respondeu que não. ${ }^{73}$

Os bilhetes foram impressos na tipografia do jornal Correio da Vitória pelo que nos informa Aprígio Guilhermino de Jesus, 28 anos, solteiro, tipógrafo, natural de Vitória, sabendo ler e escrever. Este funcionário da tipografia, ao ser perguntado se a tipografia enviou um exemplar do bilhete impresso ao promotor público como previa a lei, respondeu que não. Aprígio Guilhermino, que também comprara um bilhete de rifa, declara ainda que não sabia "quem tirou o prêmio ou relógio rifado, por não se ter importado disso desde que seu bilhete saiu branco" ${ }^{74}$ Não seria necessário interrogar este tipógrafo do Correio da Vitória, a não ser para obter a confirmação de que os bilhetes foram ali impressos, porque Manoel Pinto de Azevedo Maciel, 30 anos, solteiro, negociante, natural e morador em Vitória, sabendo ler e escrever, que era outro comprador da rifa, declara ao ser interrogado que a impressão foi feita na tipografia do Correio da Vitória "porque nos próprios bilhetes está declarado o nome do mesmo estabelecimento". ${ }^{75}$

A parte mais reveladora de toda esta história de uma rifa que ao que tudo indica Manoel Ferreira Dias não teve maiores dificuldades em vender, tendo ainda a sorte de ter o seu próprio filho como ganhador, se encontra no depoimento de outro comprador da rifa, o empregado público Philomeno de Andrade Gomes Rezende, 28 anos, solteiro, natural e morador em Vitória, sabendo ler e escrever. Quando interrogado pelo chefe de polícia e em presença do promotor público, lhe foram feitas, dentre outras, as seguintes perguntas: 
Perguntado quantos bilhetes foram rifados e o valor de cada um? Respondeu que quanto ao número de bilhetes não sabe, e que são do valor de $3 \$ 000$ cada um; e que ele testemunha ainda possui um bilhete dessa rifa. Perguntado se pode ceder ao chefe de polícia esse bilhete? Respondeu que sim, e cede ao referido Dr. chefe de polícia visto não servir-lhe mais. ${ }^{76}$

Neste ponto dos autos consta a seguinte observação do escrivão: "Neste ato retirou-se o Dr. Promotor Público por achar-se incomodado." 77

O que estaria incomodando o promotor público? Não temos como saber com exatidão, mas temos fortes suspeitas de que era a própria naturalidade com que as testemunhas viam a contravenção em questão.

Nesse caso, não era só o promotor público que devia se sentir incomodado. A reação de desqualificação do delito por parte das testemunhas colocava em questão a própria função da justiça. Era como se estas pessoas quisessem dizer às autoridades policiais e judiciárias que elas não deviam se envolver com estas pequenas questões, as quais poderiam ser resolvidas por elas mesmas, sem a sua intervenção.

A polícia e a justiça tinham a sua ação validada apenas dentro de certos limites, que embora imprecisos, eram concretos. Isto se aplicava principalmente à polícia. Esta frequentemente era vista como incômoda, abusiva e dispensável. Estamos certos de que, mais do que serem enquadradas pela polícia, as pessoas procuravam enquadrá-la no limite do que desejavam ou do que consideravam razoável.

\section{Notas}

${ }^{1}$ FRANCO, Maria Sylvia C. Homens livres na ordem escravocrata. 4ª ed. São Paulo: Editora da Unesp, 1997, p. 17.

${ }^{2}$ VELLASCO, Ivan A. As seduçôes da ordem: violência, criminalidade e administração da justiça; Minas Gerais, século XIX. Bauru: Editora da Edusc/ Anpocs, 2000, p. 216.

${ }^{3}$ BRETAS, Marcos Luiz. A guerra das ruas: povo e policia na cidade do Rio de Janeiro. Rio de Janeiro: Arquivo Nacional, 1997, p. 20-21.

${ }^{4}$ Espírito Santo, Lei de 14 de junho de 1892 - no 3 - Da organização policial do Estado, Typographia do Estado do Espírito Santo, Vitória, p. 25 e 26.

${ }^{5}$ CAMPOS, Adriana P. Crime e escravidão: uma interpretação alternativa. In: CARVALHO, José Murilo de (Org.). Nação e cidadania: novos horizontes. Rio de Janeiro: Civilização Brasileira, 2007, p. 230.

${ }^{6}$ BRETAS, Marcos Luiz. A Polícia carioca no Império. Estudos Históricos, v. 12, no 22, 1998, p. 220.

${ }^{7}$ APEES (Arquivo Público do Estado do Espírito Santo), Inquérito nº 729, Cx. 681, 1882, Diversos sobre infração de posturas, vagabundagem etc., 7 autos, 15 fls. manuscritas.

${ }^{8}$ APEES, Inq. $\mathrm{n}^{\circ}$ 729, Cx. 681, 1882, inq. cit.

${ }^{9}$ APEES, Inq. no 729 , Cx. 681, 1882, inq. cit.

${ }^{10}$ APEES, Inq. $\mathrm{n}^{\circ} 729$, Cx. 681, 1882, inq. cit.

${ }^{11}$ APEES, Inq. no 729, Cx. 681, 1882, inq. cit.

${ }^{12}$ APEES, Inquérito no 609, Cx. 676, 22.05.1880, Termo de bem viver, ex-officio, João Arthur Tesch Horta de Oliveira, acusado, 10 fls. não numeradas manuscritas, fl. 2. Referindo-se ao Dr. Herculano Matos Inglês de Souza, nomeado presidente da província do Espírito Santo por carta imperial de 24 de março de 1882, Maria Stella de Novaes nota que "preocupou-se este presidente em estimular o povo ao emprego sensato e eficiente do tempo. Na mensagem apresentada à assembleia legislativa, registrou que instituíra o termo de bem-viver, que deveria ser assinado pelos indivíduos ociosos, desocupados, que viviam na miséria e na vagabundagem". Com mais esse elogio, entre tantos outros dirigidos às personalidades da época que aparecem em seu livro, Maria Stella de Novaes acaba por nos dar uma ideia precisa do que se pretendia quando se condenava alguém a assinar este termo. NOVAES, Maria Stella de. História do Espirito Santo. Vitória: Fundo Editorial do Espírito Santo, s.d., p. 284.

${ }^{13}$ APEES, Inq. no 609, Cx. 676, 22.05.1880, inq. cit., fl. 5.

${ }^{14}$ APEES, Inq. $\mathrm{n}^{\mathrm{o}}$ 609, Cx. 676, 22.05.1880, inq. cit., fl. 5.

${ }^{15}$ APEES, Inq. $\mathrm{n}^{\circ}$ 609, Cx. 676, 22.05.1880, inq. cit., fl. 8.

${ }^{16}$ APEES, Inq. $\mathrm{n}^{\mathrm{o}}$ 609, Cx. 676, 22.05.1880, inq. cit., fl. 6. 
${ }^{17}$ APEES, Inquérito no 698, Cx. 680, 03.11.1882, Termo de bem viver, A Justiça, Possidônia Maria da Conceição, ré, 13 fls. manuscritas, fl. 5 .

${ }^{18}$ APEES, Inq. no 698, Cx. 680, 03.11.1882, inq. cit., fls. 7 e 8.

${ }^{19}$ APEES, Inq. no 698, Cx. 680, 03.11.1882, inq. cit., fl. 7.

${ }^{20}$ HOLLOWAY, Thomas. Polícia no Rio de Janeiro: repressão e resistência numa cidade do século XIX. Tradução de Francisco C. Azevedo. Rio de Janeiro: Editora da Fundação Getúlio Vargas, 1997, p. 25.

${ }^{21}$ FAUSTO, Boris. Crime e cotidiano: a criminalidade em São Paulo (1880-1924). São Paulo: Brasiliense, 1984 , p. 42.

${ }^{22}$ Idem, Ibid, p. 42.

${ }^{23}$ Ibid, p. 43.

${ }^{24}$ CASTEL, Robert. Les métamorphoses de la question sociale: une chronique du salariat. Paris: Fayard, 1995, p. 342.

${ }^{25}$ Brasil, Recenseamento do Brazil de 1872, Espírito Santo, p. 1.

${ }^{26}$ Brasil, População recenseada em 31 de dezembro de 1890. Rio de Janeiro: Officina da Estatística, 1898, p. 32 e 33.

${ }^{27}$ Brasil, Recenseamento do Brazil de 1872, Espírito Santo..., recenc. cit., p. 1.

${ }^{28}$ Brasil, População recenseada em 31 de dezembro de 1890..., recenc. cit., p. 238.

${ }^{29}$ KUZNESOF, Elizabeth A. Ilegitimidade, raça e laços de família no Brasil do século XIX: uma análise da informação de censos e de batismos para São Paulo e Rio de Janeiro. In: NADALIN, Sergio Odilon; MARCILIO, Maria Luiza \& BALHANA, Altiva P. (Orgs.). Congresso sobre a história da população da América Latina (1989: Ouro Preto, MG). História e População: estudos sobre a América Latina. São Paulo: Fundação Sistema Estadual de Análise de Dados, 1990, p. 166-167.

${ }^{30}$ Brasil, População recenseada em 31 de dezembro de 1890..., recenc. cit., p. 238.

${ }^{31}$ Espírito Santo, Contendo leis e resoluções promulgadas pela Assembleia Legislativa na 1a sessão ordinária da 24 a legislatura em 1880 (Lei no 21)..., artigos 71 e 72, p. 52-53.

32 APEES, Inquérito no 679, Cx. 679, 27.05.1882, Processo Policial, João Brand, réu, 22 fls. manuscritas, fl. 4.

${ }^{33}$ APEES, Inq. no 679, Cx. 679, 27.05.1882, inq. cit., fls. 11 e 12.

${ }^{34}$ APEES, Inquérito no 713, Cx. 680, 20.08.1882, Uso de armas proibidas, A justiça, Francisco José da Silva, réu, 14 fls. manuscritas, fl. 6.

${ }^{35}$ APEES, Inq. no 713, Cx. 680, 20.08.1882, inq. cit., fl. 6.

${ }^{36}$ APEES, Inquérito no 897, Cx. 689, 20.07.1885, Auto de perguntas feitas à Antonietta Argentina e outras, 3 fls não numeradas. manuscritas, fls. 1 e 2.

${ }^{37}$ FOUCAULT, Michel. Surveiller et punir: naissance de la prison. Paris: Gallimard, 1975, p. 249.

${ }^{38}$ HOLLOWAY, Thomas. Polícia no Rio de Janeiro..., op. cit., p. 263.

${ }^{39}$ APEES, Inquérito no 559, Cx. 673, 04.07.1879, Inquérito Policial, Ex-offício, Antônio Damázio Camillo, vulgo “Trem”, 10 fls. não numeradas manuscritas, fls. 3 e 4.

${ }^{40}$ SOUZA, Laura de M. Desclassificados do ouro: a pobreza mineira no século XVIII. Rio de Janeiro: Graal, 1986, p. 185.

${ }^{41}$ APEES, Inquérito no 559, Cx. 673, 04.07.1879, inq. cit., fls. 5 e 6.

${ }^{42}$ APEES, Inq. no 559, Cx. 673, 04.07.1879, inq. cit., fl. 6.

${ }^{43}$ APEES, Inq. no 559, Cx. 673, 04.07.1879, inq. cit., fls. 8 e 9.

${ }^{44}$ APEES, Inq. no 559, Cx. 673, 04.07.1879, inq. cit., fl. 9.

${ }^{45}$ APEES, Inq. no 559, Cx. 673, 04.07.1879, inq. cit., fls. 9 e 10.

${ }^{46}$ APEES, Inq. no 559, Cx. 673, 04.07.1879, inq. cit., fl. 10.

${ }^{47}$ VELLASCO, Ivan A. Policiais, pedestres e inspetores de quarteirão: algumas questōes sobre as vicissitudes do policiamento na província de Minas Gerais. In: CARVALHO, José Murilo de (Org.). Nação e cidadania: novos horizontes. Rio de Janeiro: Civilização Brasileira, 2007, p. 254.

${ }^{48}$ APEES, Inquérito no 824, Cx. 685, 23.12.1884, Summario Crime, A Justiça, João Ferreira da Silva e Victorino Thomaz Dantas, réus, 88 fls. manuscritas, fl. 40.

${ }^{49}$ APEES, Inq. no 824, Cx. 685, 23.12.1884, inq. cit., fl. 35.

${ }^{50}$ BRETAS, Marcos Luiz. A guerra das ruas..., op. cit., p. 22.

${ }^{51}$ APEES, Inquérito no 638, Cx. 677, 06.12.1881, Responsabilidade, A justiça, Juvêncio da Rocha Coutinho, carcereiro da cadeia desta capital, réu, 16 fls. manuscritas, fls. 7 e 8.

${ }^{52}$ APEES, Inq. no 638, Cx. 677, 06.12.1881, inq. cit., fl. 11. 
${ }^{53}$ HOGGART, Richard. La culture du pauvre: étude sur le style de vie des classes populaires en Angleterre. Paris: Les Editions de Minuit, 1970, p. 118.

${ }^{54}$ VELLASCO, Ivan A. Policiais, pedestres e inspetores de quarteirão..., op. cit., p. 254.

${ }^{55}$ APEES, Inquérito no 1131, Cx. 702, 29.01.1890, Inquérito Policial, João Coutinho da Victoria, réu, 7 fls. manuscritas, fl. 3.

${ }^{56}$ APEES, Inq. no 1131, Cx. 702, 29.01.1890, inq. cit., fls. 6 e 7.

${ }^{57}$ APEES, Inq. no 1131, Cx. 702, 29.01.1890, inq. cit., fl. 6.

${ }^{58}$ REVEL, Jacques \& FARGE, Arlette. As regras do motim: o caso dos raptos de crianças (Paris, maio de 1750). In: REVEL, Jacques. A invenção da sociedade. Tradução de Vanda Anastácio. Lisboa / Rio de Janeiro: Difel / Bertrand Brasil, s. d., p. 232.

${ }^{59}$ APEES, Inquérito no 1356, Cx. 714, 18.01.1897, Summario Crime, A Justiça, Capitão Joaquim Barboza dos Santos, Tenente Elísio Nogueira da Gama, Alferes Aristides José do Carmo, réus, 21 fls. manuscritas, fl. 8.

${ }^{60}$ APEES, Inquérito no 875, Cx. 687, 22.11.1884, Summario Crime, A Justiça, Marcellino, escravo de Manoel Vieira de Mattos, Florêncio, escravo de D. Triphina dos Santos Pinto, réus, 54 fls., fl. 13.

${ }^{61}$ APEES, Inq. no 1356, Cx. 714, 18.01.1897, inq. cit., fl. 12.

${ }^{62}$ FOUCAULT, Michel. Surveiller et punir..., op. cit., p. 75.

${ }^{63}$ APEES, Inquérito no 517, Cx. 671, 30.08.1877, Injúrias, A Promotoria Pública, denunciante, José Goulart de Souza, denunciado, 18 fls. manuscritas, fl. 5.

${ }^{64}$ APEES, Inq. no 517, Cx. 671, 30.08.1877, inq. cit., fl. 8.

${ }^{65}$ APEES, Inq. no 517, Cx. 671, 30.08.1877, inq. cit., fl. 10.

${ }^{66}$ APEES, Inq. no 517, Cx. 671, 30.08.1877, inq. cit., fl. 10.

${ }^{67}$ THOMPSON, Edward P. Senhores e caçadores: a origem da Lei Negra. Tradução de Denise Bottmann. Rio de Janeiro, Paz e Terra, 1987. p. 338.

${ }^{68}$ APEES, Inquérito no 465, Cx. 668, 09.05.1874, Responsabilidade, Jacintho Escobar Araujo, réu, 28 fls. manuscritas, fls. 2 e 3.

${ }^{69}$ APEES, Inq. no 465, Cx. 668, 09.05.1874, inq. cit., fl. 24.

${ }^{70}$ APEES, Inq. no 465, Cx. 668, 09.05.1874, inq. cit., fls. 9 e 10.

${ }^{71}$ VELLASCO, Ivan A. As seduções da ordem..., op. cit., p. 181.

${ }^{72}$ APEES, Inquérito no 375, Cx. 664, 25.11.1872, Processo Policial Ex officio de Manoel Ferreira Dias, 16 fls. manuscritas, fl. 2.

${ }^{73}$ APEES, Inq. no 375, Cx. 664, 25.11.1872, inq. cit., fls. 5 e 6.

${ }^{74}$ APEES, Inq. no 375, Cx. 664, 25.11.1872, inq. cit., fl. 8.

${ }^{75}$ APEES, Inq. no 375, Cx. 664, 25.11.1872, inq. cit., fl. 9.

${ }^{76}$ APEES, Inq. no 375, Cx. 664, 25.11.1872, inq. cit., fl. 7.

${ }^{77}$ APEES, Inq. no 375, Cx. 664, 25.11.1872, inq. cit., fl. 7.

\section{Fontes}

APEES (Arquivo Público do Estado do Espírito Santo), Inquérito no 375, Cx. 664, 25.11.1872, Processo Policial Ex officio de Manoel Ferreira Dias, 16 fls. manuscritas.

APEES, Inquérito no 465, Cx. 668, 09.05.1874, Responsabilidade, Jacintho Escobar Araujo, réu, 28 fls. manuscritas.

APEES, Inquérito no 517, Cx. 671, 30.08.1877, Injúrias, A Promotoria Pública, denunciante, José Goulart de Souza, denunciado, 18 fls. manuscritas.

APEES, Inquérito no 559, Cx. 673, 04.07.1879, Inquérito Policial, Ex-offício, Antônio Damázio Camillo, vulgo "Trem", 10 fls. não numeradas manuscritas.

APEES, Inquérito no 609, Cx. 676, 22.05.1880, Termo de bem viver, ex-officio, João Arthur Tesch Horta de Oliveira, acusado, 10 fls. não numeradas manuscritas.

APEES, Inquérito no 638, Cx. 677, 06.12.1881, Responsabilidade, A justiça, Juvêncio da Rocha Coutinho, carcereiro da cadeia desta capital, réu, 16 fls. manuscritas.

APEES, Inquérito no 679, Cx. 679, 27.05.1882, Processo Policial, João Brand, réu, 22 fls. manuscritas.

APEES, Inquérito no 698, Cx. 680, 03.11.1882, Termo de bem viver, A Justiça, Possidônia Maria da Conceição, ré, 13 fls. manuscritas. 
APEES, Inquérito no 713, Cx. 680, 20.08.1882, Uso de armas proibidas, A justiça, Francisco José da Silva, réu, 14 fls. manuscritas.

APEES, Inquérito no 729, Cx. 681, 1882, Diversos sobre infração de posturas, vagabundagem etc., 7 autos, 15 fls. manuscritas.

APEES, Inquérito no 824, Cx. 685, 23.12.1884, Summario Crime, A Justiça, João Ferreira da Silva e Victorino Thomaz Dantas, réus, 88 fls. manuscritas.

APEES, Inquérito no 875, Cx. 687, 22.11.1884, Summario Crime, A Justiça, Marcellino, escravo de Manoel Vieira de Mattos, Florêncio, escravo de D. Triphina dos Santos Pinto, réus, $54 \mathrm{fls}$.

APEES, Inquérito no 897, Cx. 689, 20.07.1885, Auto de perguntas feitas à Antonietta Argentina e outras, 3 fls não numeradas, manuscritas.

APEES, Inquérito no 1131, Cx. 702, 29.01.1890, Inquérito Policial, João Coutinho da Victoria, réu, 7 fls. manuscritas.

APEES, Inquérito no 1356, Cx. 714, 18.01.1897, Summario Crime, A Justiça, Capitão Joaquim Barboza dos Santos, Tenente Elísio Nogueira da Gama, Alferes Aristides José do Carmo, réus, 21 fls. manuscritas.

Brasil, Recenseamento do Brazil de 1872, Espírito Santo.

Brasil, População recenseada em 31 de dezembro de 1890. Rio de Janeiro: Officina da Estatística, 1898.

Espírito Santo, Contendo leis e resoluçôes promulgadas pela Assembleia Legislativa na 1a sessão ordinária da 24 a legislatura em 1880 (Lei no 21), artigos 71 e 72.

Espírito Santo, Lei de 14 de junho de 1892 - no 3 - Da organização policial do Estado, Typographia do Estado do Espírito Santo, Vitória.

\section{Referências bibliográficas}

BRETAS, Marcos Luiz. A Polícia carioca no Império. Estudos Históricos, v. 12, no 22, p. 219-234, 1998. . A guerra das ruas: povo e polícia na cidade do Rio de Janeiro. Rio de Janeiro: Arquivo Nacional, 1997.

CAMPOS, Adriana P. Crime e escravidão: uma interpretação alternativa. In: CARVALHO, José Murilo de (Org.). Nação e cidadania: novos horizontes. Rio de Janeiro: Civilização Brasileira, 2007, p. 207-235.

CASTEL, Robert. Les métamorphoses de la question sociale: une chronique du salariat. Paris: Fayard, 1995.

FAUSTO, Boris. Crime e cotidiano: a criminalidade em São Paulo (1880-1924). São Paulo: Brasiliense, 1984.

FOUCAULT, Michel. Surveiller et punir: naissance de la prison. Paris: Gallimard, 1975.

FRANCO, Maria Sylvia C. Homens livres na ordem escravocrata. $4^{a}$ ed. São Paulo: Editora da Unesp, 1997.

HOGGART, Richard. La culture du pauvre: étude sur le style de vie des classes populaires en Angleterre. Paris: Les Editions de Minuit, 1970.

HOLLOWAY, Thomas. Polícia no Rio de Janeiro: repressão e resistência numa cidade do século XIX. Tradução de Francisco C. Azevedo. Rio de Janeiro: Editora da Fundação Getúlio Vargas, 1997.

KUZNESOF, Elizabeth A. Ilegitimidade, raça e laços de família no Brasil do século XIX: uma análise da informação de censos e de batismos para São Paulo e Rio de Janeiro. In: NADALIN, Sergio Odilon; MARCILIO, Maria Luiza \& BALHANA, Altiva P. (Orgs.). Congresso sobre a história da população da América Latina (1989: Ouro Preto, MG). História e População: estudos sobre a América Latina. São Paulo: Fundação Sistema Estadual de Análise de Dados, 1990, p. 164-174.

NOVAES, Maria Stella de. História do Espirito Santo. Vitória: Fundo Editorial do Espírito Santo, s.d.

REVEL, Jacques \& FARGE, Arlette. As regras do motim: o caso dos raptos de crianças (Paris, maio de 1750). In: REVEL, Jacques. A invenção da sociedade. Tradução de Vanda Anastácio. Lisboa / Rio de Janeiro: Difel / Bertrand Brasil, s. d., p. 217-236.

SOUZA, Laura de M. Desclassificados do ouro: a pobreza mineira no século XVIII. Rio de Janeiro: Graal, 1986.

THOMPSON, Edward P. Senhores e caçadores: a origem da Lei Negra. Tradução de Denise Bottmann. Rio de Janeiro: Paz e Terra, 1987. 
VELLASCO, Ivan A. Policiais, pedestres e inspetores de quarteirão: algumas questōes sobre as vicissitudes do policiamento na província de Minas Gerais. In: CARVALHO, José Murilo de (Org.). Nação e cidadania: novos horizontes. Rio de Janeiro: Civilização Brasileira, 2007, p. 237-265.

As seduçôes da ordem: violência, criminalidade e administração da justiça; Minas Gerais, século XIX. Bauru: Editora da Edusc / Anpocs, 2000.

\title{
RESUMO
}

A partir da análise de inquéritos policiais procuramos perceber como os indivíduos que viviam em Vitória (Espirito Santo, Brasil), no final do século XIX, se relacionavam com a polícia. O que nos interessa são as respostas que essas pessoas davam à ação da polícia a partir da perspectiva de que os policiais, ou os representantes da ordem pública, eram muito próximos daqueles que, em princípio, eles deviam manter em ordem. As funçôes e limites da polícia deviam ser redefinidos a cada momento pelas relaçôes interpessoais na cidade já que a autoridade tinha de ser afirmada e reconhecida em cada situação.

Palavras-chave: ação policial, reação individual, inquéritos policiais, Vitória, século XIX.

\begin{abstract}
From the analysis of police inquests we try to figure out how the people who lived in the town of Victoria (Brazil) by the end of the nineteenth century dealt with the police work. We are interested in the ordinary citizen's responses to the police law enforcement action, mainly from the policeman standpoint or else, from the perspective of the ones responsible for the maintenance of public order, since they were individuals from the same social milieu than those they had to keep under control. So, their role and scope of action were constantly redefined according to their interpersonal relations, for the authority principle had to be affirmed and recognized at each situation.

Keywords: police action, individual reaction, police investigations, Vitória, 19th century.
\end{abstract}

